\title{
Implementacija modela LRM: konceptualna zasnova uporabniškega vmesnika za katalogizacijo
}

\author{
LRM implementation: conceptual design of a cataloging user interface
}

\section{Mihela Pauman Budanović ${ }^{1}$ in Maja Žumer ${ }^{2}$}

IZVLEČEK: Spremembe v konceptualizaciji bibliografskih podatkov, ki jih je povzročila uvedba modela IFLA LRM, so močno vplivale na razvoj in reorganizacijo katalogizacijskih načel in pravil, bibliografskih formatov in bibliografskih informacijskih sistemov. Kljub temu pa pri implementaciji LRM še vedno primanjkuje smernic in primerov praks, ki bi pokazale, kako vse komponente modela dosledno implementirati v katalogizacijske sisteme, kar smo poskušali obravnavati s predlogom konceptualne zasnove uporabniškega vmesnika za katalogizacijo na osnovi modela LRM. Pripravili in preverili smo prototip na papirju, kar je pogosta prva faza v razvoju programske opreme. Članek povzema prvi cikel oziroma ponovitev $v$ življenjskem ciklu razvoja prototipa, ki se nanaša na našo implementacijo. Predlagani prototip predstavlja eno prvih točnih implementacij modela LRM $\vee$ katalogizacijske vmesnike.

KLJUČNE BESEDE: IFLA Library Reference Model (LRM), katalogizacija, konceptualna zasnova, zasnova uporabniškega vmesnika, katalogizacijski sistemi

ABSTRACT: Changes in the conceptualization of bibliographic data caused by the introduction of the IFLA LRM model have strongly influenced the development and reorganization of cataloging principles and rules, bibliographic formats, and bibliographic information systems. Nevertheless, there is still a lack of both guidance and practices in LRM implementation to show how all the components should be applied consistently in cataloging systems, which we have tried to address by proposing a conceptual design for a cataloging user interface based on the LRM model. We prepared and tested a paper prototype, which is often the first stage in software development. The article summarizes the first cycle or iteration in a prototype development life cycle as applied in our implementation. The proposed prototype presents one of the first faithful implementations of the LRM model in cataloging interfaces.

KEYWORDS: IFLA Library Reference Model (LRM), cataloging, conceptual design, user interface design, cataloging systems

\section{Uvod}

Konceptualni okvir katalogizacijske teorije in prakse, ki je bil v veliki meri nespremenjen že od šestdesetih let prejšnjega stoletja in je zaznamovan s sprejetjem Pariških načel in razvojem formatov MARC, se v luči elektronskega okolja in trendov, ki jih prinaša semantični splet, postopoma spreminja in preoblikuje. Pomemben korak na poti do spremembe zastarele paradigme knjižničnega kataloga predstavlja razvoj modelov iz družine FR in sprejetje modela

Članek je nastal na osnovi doktorske disertacije Pauman Budanović, M., 2019. Konceptualna zasnova sistema za katalogizacijo na osnovi nove paradigme bibliografskega univerzuma. Disertacija. Ljubljana: Univerza v Ljubljani, Filozofska fakulteta.

${ }^{1}$ Korespondenčni avtor: asist. dr. Mihela Pauman Budanović, Univerza v Ljubljani, Filozofska fakulteta,

mihela.paumanbudanovic@ff.uni-lj.si.

${ }^{2}$ Red. prof. dr. Maja Žumer, Univerza v Ljubljani, Filozofska fakulteta, maja.zumer@ff.uni-li.si. 
IFLA Library Reference Model (LRM) (Riva et al., 2017). Entitetno-relacijski model LRM z uvajanjem drugačnih konceptov obdelave, shranjevanja in uporabe bibliografskih informacij katalogizacijo postavlja na nove temelje ter prinaša največjo prevetritev katalogizacijske teorije in prakse od uvedbe online katalogov.

Doslej je bila večina prizadevanj na področju implementacije modela LRM usmerjena predvsem na katalogizacijska pravila (npr. RDA - Resource Description and Access) in bibliografske formate (npr. BIBFRAME), ki bodo bolj uporabni v okolju povezanih podatkov. Čeprav bi LRM lahko pomagal premagati nekatere pomanjkljivosti katalogizacijskih sistemov, mnogi avtorji pojasnjujejo, da $v$ trenutnih katalogizacijskih sistemih ne moremo izkoristiti potenciala konceptualnih modelov (oziroma RDA) v polni meri, ker sistemi niso sposobni odražati entitetno-relacijskega modela (Cronin, 2011; Wacker in Han, 2013; Park in Tosaka, 2015; Dunsire et al., 2020).

Razvoj katalogizacijskih sistemov po svetu že poteka v smeri implementacije modela LRM, a so bili dosedanji poskusi tovrstnih implementacij redki in zelo omejeni. Ker še vedno primanjkuje smernic in primerov praks pri implementaciji LRM, ki bi pokazale, kako vse komponente modela dosledno implementirati v katalogizacijske sisteme, je eden od večjih izzivov ustvariti katalogizacijski sistem, ki zagotavlja učinkovit in uspešen vnos podatkov na podlagi izkoriščanja njegovih prednosti, kar je bila motivacija za našo raziskavo.

Namen prispevka je predstavitev konceptualne zasnove uporabniškega vmesnika za katalogizacijo, ki upošteva tako novo paradigmo bibliografskega univerzuma (torej konceptualni model IFLA LRM ter na tej podlagi tudi nova mednarodna katalogizacijska načela in $v$ določeni meri katalogizacijska pravila RDA) kot tudi razmišljanje slovenskih katalogizatorjev, ki izhaja iz predhodnih raziskav.

\section{Implementacije modela LRM v katalogizacijska orodja}

Harmonizirani model IFLA LRM, ki integrira in usklajuje tri modele iz družine FR, uvaja celovit konceptualni model bibliografskega univerzuma ter predstavlja sodobno in $s$ koncepti semantičnega spleta usklajeno osnovo za razvoj katalogizacijskih načel in pravil, pa tudi za nove bibliografske formate in bibliografske informacijske sisteme (Riva et al., 2017). Model LRM je na kratko opisan $v$ poglavju 3.1.2, v nadaljevanju pa so predstavljene najvidnejše implementacije Iflinega modela $v$ katalogizacijska orodja, ki predstavljajo pomembne premike na poti k novemu katalogizacijskemu ustroju. $\mathrm{Na}$ splošno so katalogizacijska orodja opredeljena kot vse naprave ali dokumenti $v$ tiskani ali elektronski obliki, ki pomagajo pri kreiranju bibliografskih zapisov (Miksa, 2008). Ker je katalogizacijska praksa zelo odvisna od tega, kako so načela navedena in implementirana ne samo $v$ pravilih, ampak tudi $v$ katalogizacijskem sistemu, močan vpliv LRM in njegovih predhodnikov iz družine FR prinaša pomembne spremembe $v$ katalogizacijska orodja.

\subsection{Izjava o mednarodnih katalogizacijskih načelih}

Ifla je leta 2009 objavila nova mednarodna katalogizacijska načela Statement of international cataloguing principles, ki so v slovenskem prevodu izšla z naslovom Izjava o mednarodnih katalogizacijskih načelih (Izjava, 2009). Zaradi usklajevanja z modeli FRBR, FRAD in FRSAD so bila leta 2016 načela revidirana in uvajajo nekatere vsebinske in terminološke spremembe. Izdajo načel iz leta 2009 je nadomestila revidirana in posodobljena izdaja (Kavčič in Šulek, 
2017b). Nova mednarodna katalogizacijska načela nadomeščajo in razširjajo Pariška načela iz leta 1961 ter predstavljajo vodilo za razvoj novih, sodobnejših katalogizacijskih pravilnikov po vsem svetu. Načela temeljijo na uveljavljenih katalogizacijskih praksah po svetu in na družini konceptualnih modelov FR, pri tem pa se osredotočajo na trenutno okolje knjižničnih katalogov in drugih bibliografskih informacijskih sistemov. Za razliko od Pariških načel so ta načela namenjena opisu vseh vrst gradiva in se nanašajo na vse vidike bibliografskih in normativnih podatkov (ne le na izbor in obliko vstopnega elementa oziroma iztočnice), ki se uporabljajo v knjižničnih katalogih, omogočajo pa tudi sodelovanje $z$ drugimi skupnostmi $s$ področja varstva kulturne dediščine, kot so arhivi in muzeji. Njihov namen je zagotoviti konsistenten pristop tako k opisni katalogizaciji kot tudi vsebinski obdelavi vseh vrst gradiva (Kavčič in Šulek, 2017b).

\subsection{Katalogizacijska pravila}

Iflini konceptualni modeli so postavili nov okvir tudi za katalogizacijske pravilnike. Potreba po bolj konsistentnih in fleksibilnih pravilih za opis vseh vrst virov in vsebin, po kompatibilnosti z mednarodno sprejetimi načeli, modeli in standardi ter po prilagoditvi opisa virov drugim skupinam uporabnikov (muzejem, arhivom, založnikom ipd.) je privedla do nastanka novih pravil. Na podlagi FRBR oziroma LRM so bila razvita katalogizacijska pravila, ki upoštevajo nova katalogizacijska načela; to so npr. Resource Description and Access (2010) - anglo-ameriška pravila, ki jih prevzema vse več držav po svetu; Regole Italiane di Catalogazione (Regole, 2009) - italijanska pravila in Pravilnik za opis i pristup građi u knjižnicama, arhivima i muzejima (KAM, 2021) - hrvaška pravila. Tudi RDA Toolkit, glavno orodje in vodilo za katalogizacijo po RDA, je bil nedavno prenovljen in je zdaj usklajen z LRM (RDA Toolkit, 2021).

Kar zadeva RDA v Sloveniji, še čakamo na njegovo implementacijo, ki je predvidena za leto 2024 (Behrens, 2020). Kot navajata Kavčič in Šulek (2017a), pa vse spremembe na področju katalogizacije tudi pri nas že usklajujemo s standardom RDA. Avtorici menita, da bi bilo smiselno nekatere pomanjkljivosti odpraviti že pred posodobitvijo katalogizacijskih pravil ter da za to ni treba čakati na prevod in implementacijo RDA.

\subsection{BIBFRAME}

Kot odgovor na potrebo po drugačnem okviru za prikaz in izmenjavo bibliografskih podatkov je Kongresna knjižnica razvila konceptualni model BIBFRAME, ki je zasnovan na principih povezanih podatkov in standardov na področju semantične interoperabilnosti. Model BIBFRAME sestavljajo naslednji trije glavni razredi (tudi entitete): delo, primerek in enota. Z glavnimi razredi so povezani še dodatni koncepti: agenti, vsebina in dogodki.

BIBFRAME bi s svojimi potenciali v prihodnosti lahko nadomestil format MARC, ki je z vidika implementacije modela LRM v kataloge neustrezen (Hall-Ellis, 2015), vendar razvoj BIBFRAME od vsega začetka (leta 2011) poteka počasi; trenutno prehaja iz raziskovalne oziroma poskusne faze v fazo, ki obeta širšo implementacijo tudi zunaj Kongresne knjižnice. Čeprav se BIBFRAME že intenzivno uporablja predvsem v Kongresni knjižnici, je v prihodnosti realno še kar nekaj let pričakovati soobstoj zapisov BIBFRAME in zapisov MARC (Kim et al., 2021).

Kongresna knjižnica je v okviru projekta razvila številna orodja, ki so prostodostopna na njihovi spletni strani (Bibliographic Framework Initiative, 2021): BIBFRAME Editor je primer urejevalnika za vnos podatkov, orodji MARC to BIBFRAME comparison viewer in BIBFRAME to 
MARC comparison viewer omogočata primerjavo zapisov $v$ obeh formatih (MARC21 in RDF), orodji BIBFRAME 2.0 to MARC 21 Conversion in MARC 21 to BIBFRAME 2.0 Conversion pa preoblikovanje zapisov iz formata MARC/XML $v$ format BIBFRAME in obratno.

\subsection{Katalogizacijski sistemi}

Številni komercialni ponudniki knjižničnih informacijskih sistemov so sicer posvečali kar nekaj pozornosti razvoju katalogizacijskih sistemov na osnovi modela FRBR oziroma LRM, npr. Virtua Catalogue (razvijalec VTLS), VisualCat (razvijalec Portia), AquaBrowser (razvijalec Serials Solutions), Endeca Catalogue (razvijalec Ex Libris) itd., a so sistemi kljub temu ostali tesno povezani z dosedanjo katalogizacijsko prakso, predvsem zaradi formata. Zelo redki pa so novi, na LRM (oz. FRBR) osnovani katalogizacijski sistemi, neodvisni od starih praks, in še ti so predvsem raziskovalne narave; to so npr. BIBFRAME Editor, RIMMF (RDA in Many Metadata Formats), Aura, LibFRBR, WeCat, Variations/FRBR Cataloging Tool, IFPA (ISIS FRBR Prototype Application) (Sturman, 2005; Riley, 2010; Sandberg, 2015; Guerrini in Possemato, 2016; Wright, 2018; Dunsire et al., 2020). Omenjeni sistemi omogočajo zanimiv vpogled v prihodnost bibliografskega opisa in na splošno organizacije informacij z novimi orodji, ki temeljijo na konceptualnih modelih.

Zaradi opisanih konceptualnih sprememb na področju katalogizacije postaja vse bolj razširjeno zavedanje, da katalogizacijska skupnost nujno potrebuje novo generacijo sistemov, ne samo v smislu tehnične infrastrukture, ampak tudi na konceptualnem nivoju. To vrzel smo poskušali zapolniti s konceptualno zasnovo uporabniškega vmesnika za katalogizacijo (veznim členom med uporabnikom, tj. katalogizatorjem, in katalogizacijskim sistemom), ki implementira model LRM, njegove entitete, atribute in relacije ter predstavlja možen način za bolj učinkovit vnos bibliografskih podatkov oziroma proces katalogizacije.

\section{Konceptualna zasnova uporabniškega vmesnika za katalogizacijo}

Cilji konceptualne zasnove uporabniškega vmesnika za katalogizacijo so:

- prikazati, kako bi lahko deloval in kako bi bil videti vmesnik za katalogizacijo, zasnovan na konceptualnem modelu LRM;

- predstaviti način za učinkovitejši vnos bibliografskih podatkov oziroma proces katalogizacije (manj podvojenega dela, ponavljanja itd.) z implementacijo modela LRM, njegovih entitet, atributov in relacij ter z vzpostavitvijo normativne kontrole za dela in izrazne oblike;

- upoštevati uporabniške potrebe katalogizatorjev in njihove miselne modele bibliografskega univerzuma.

Pri konceptualni zasnovi smo želeli doseči čim večje skladanje miselnih modelov katalogizatorjev z novim uporabniškim vmesnikom za katalogizacijo, osnovanim na LRM, zato smo bili v vseh fazah razvoja osredotočeni na naslednja dva glavna vidika:

1) miselne procese katalogizatorjev $v$ različnih kontekstih (usklajenost $s$ konceptualnim modelom LRM, med prostim opisom publikacij, med procesom katalogizacije, pri simuliranju dela z normativo del in izraznih oblik);

2) izkoriščanje prednosti konceptualnega modela LRM. 
Življenjski krog prototipnega sistema na sliki 1 prikazuje postopen razvoj prototipa, v katerem sodelujejo razvijalec in predvideni uporabniki sistema. Določene korake je treba izvesti v več ponovitvah (iteracijah), saj gre za izdelavo prototipa in njegovo postopno izboljšavo na podlagi testiranja, dokler ne dosežemo zadovoljive kakovosti. $V$ našem primeru ni bilo več iteracij, upoštevali pa smo vse faze razvoja. Zasnova sistema, ki je usmerjena v uporabnike in njihova opravila, vključuje naslednje korake: analizo uporabniških zahtev (razumevanje potreb uporabnikov), zasnovo, razvoj, uporabo in testiranje. $V$ nadaljevanju predstavimo povzetek vseh korakov v življenjskem ciklu razvoja prototipa, ki se nanaša na našo implementacijo. Podrobnejši opis konceptualne zasnove uporabniškega vmesnika za katalogizacijo je v Pauman Budanović (2019) ter Pauman Budanović in Žumer (2021a).

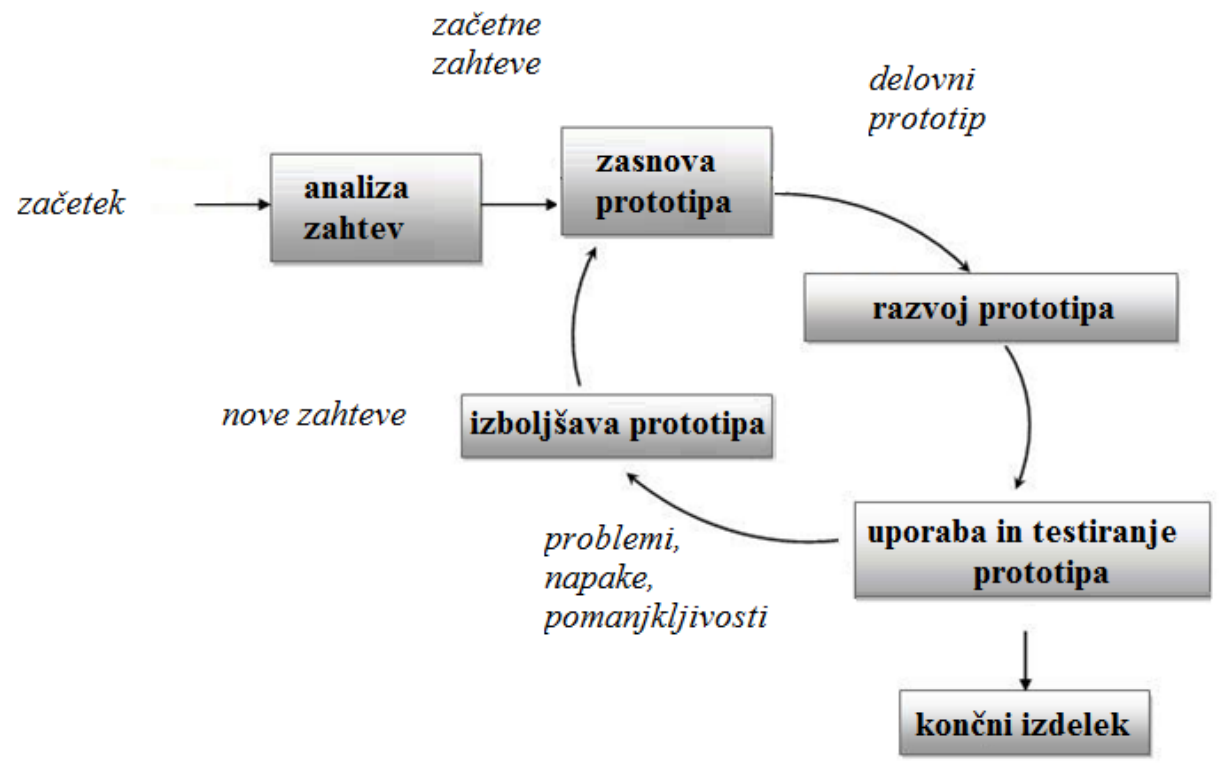

Slika 1: Prototipni model: življenjski cikel prototipnega sistema (po Masseyju in Satau, 2012)

\subsection{Analiza zahtev}

Najprej smo z raziskavami miselnih procesov katalogizatorjev in analizo modela LRM analizirali začetne zahteve (oziroma potrebe), s čimer smo pridobili ustrezna izhodišča za opredelitev funkcionalnih zahtev in konceptualno zasnovo uporabniškega vmesnika.

\subsubsection{Analiza uporabniških (katalogizatorjevih) zahtev}

Načrtovanje mora biti usmerjeno $v$ uporabnika in enostavnost uporabe, zato smo se $v$ vseh raziskavah usmerili v katalogizatorje (uporabnike) in jih kot aktivne sodelujoče vključili v vse faze razvojnega procesa, od konceptualizacije do priprave in testiranja prototipa na papirju. Sodelovanje je bilo pomembno predvsem zaradi skladanja miselnih modelov katalogizatorjev $\mathrm{z}$ novim uporabniškim vmesnikom, osnovanim na modelu LRM, hkrati pa je pripomoglo $\mathrm{k}$ pridobivanju informacij o njihovih željah, potrebah, zmožnostih, omejitvah in pričakovanjih, pa tudi $k$ pridobivanju dodatnega znanja in izkušenj. Proučevali smo miselne procese pri katalogizatorjih v različnih kontekstih in proces katalogizacije v sistemu COBISS3/Katalogizacija ter ugotavljali bistvene prednosti in slabosti sedanje katalogizacijske prakse in specifične zahteve za zasnovo ustreznega prototipnega sistema z vidika katalogizatorja. Z namenom celovitega razumevanja miselnih procesov katalogizatorjev $v$ različnih kontekstih smo pred 
konceptualno zasnovo novega katalogizacijskega sistema izvedli pet kvalitativnih raziskav, $v$ katerih je sodelovalo 119 slovenskih katalogizatorjev iz 11 knjižnic. Treba je omeniti, da so bile tako raziskave kot tudi konceptualna zasnova omejene le na leposlovje in opisno katalogizacijo. Rezultati raziskav so pokazali, da so miselni modeli katalogizatorjev zelo različni in se obravnave posamezne publikacije lotevajo na različnih ravneh abstrakcije in glede na različne kontekste uporabe. Iz zaključkov sledi tudi, da bi bil LRM lahko uporaben kot konceptualna osnova za katalogizacijo, če se dovolj dobro posvetimo njegovi implementaciji (Pauman Budanović, 2019).

\subsubsection{Analiza konceptualnega modela IFLA LRM}

$\checkmark$ tem koraku je bilo treba preučiti poročila, ki analizirajo model IFLA LRM, opredeliti specifične entitete, določiti potrebne atribute in relacije med entitetami ter določiti del bibliografskega univerzuma, ki ga bomo modelirali.

Pri implementaciji konceptualnega modela LRM je treba upoštevati, da je model precej splošen in abstrakten ter predstavlja predvsem osnovo za načrtovanje bibliografskih informacijskih sistemov in za izdelavo katalogizacijskih pravil (Riva et al., 2017). LRM, kot je prikazan $v$ poročilu, ni pripravljen za direktno implementacijo $v$ prototipni sistem. $V$ vsaki implementaciji je namreč treba ustrezno dopolniti oziroma nadgraditi atribute in relacije, ki so $v$ različnih kontekstih potrebni za končne uporabnike. Kljub temu je pri implementaciji treba upoštevati osnovno strukturo entitet in odnosov med njimi (Riva et al., 2017).

\section{- Entitete}

Model LRM uvaja 11 entitet; to so: delo, izrazna oblika, pojavna oblika, enota, agent, oseba, kolektivni agent, res, nomen, kraj in časovni razpon. Bistven okvir modela predstavljajo entitete LRM-E2 Delo, LRM-E3 Izrazna oblika, LRM-E4 Pojavna oblika in LRM-E5 Enota, na katere smo se osredotočili tudi pri konceptualni zasnovi prototipa. Te štiri entitete so glede na abstraktnost osnova za opis različnih vidikov publikacij: od abstraktnih idej, ki predstavljajo njihovo vsebino, do specifičnih fizičnih značilnosti, kot je npr. ohranjenost določene enote. $V$ konceptualno zasnovo vmesnika za katalogizacijo so bili vključeni tudi agenti. Entiteta nomen, torej poimenovanje, ki ga uporabljamo za primerek entitete, je vključena v normativo (npr. $v$ obliki imena, naslova itd.), medtem ko sta entiteti kraj in časovni razpon v prototipu modelirani kot atributa (npr. kraj in leto izida).

\section{- Atributi}

Atributi so mehanizem za določanje lastnosti primerkov entitet (Žumer, 2017). Na vsako entiteto $v$ modelu se nanašajo določeni atributi, ki so v pomoč uporabnikom pri oblikovanju poizvedb ali razlagi zadetkov, ko iščejo oziroma najdejo informacije o določeni entiteti (Funkcionalne zahteve za bibliografske zapise, 2000).

Po navedbah avtorjev so v LRM-ju ob upoštevanju vseh vrst knjižničnega gradiva definirani le najpomembnejši in najpogostejši atributi, ki zagotavljajo celovitost. Pri implementaciji je treba upoštevati, da nabor 37 atributov v LRM nikakor ni izčrpen oziroma popoln ter da nobeden od atributov ni obvezen (Riva et al., 2017). Prav tako so v mnogih primerih definirani atributi za posamezne entitete preveč generični, zato jih je treba dopolniti in nadgraditi. Ker LRM predstavlja le strukturo oziroma ogrodje, je pri vsaki implementaciji treba dodajati nujne atribute znotraj predvidenega okvira in na predviden način. Dodani so lahko povsem novi vidiki 
ali pa podatributi že določenih. Katalogizacijska pravila pa določajo njihovo izbiro, obliko (kot vrednost iz kontroliranega slovarja, kot prosto besedilo $v$ določenem jeziku in pisavi, kot numerično vrednost) in obveznost (Žumer, 2017).

\section{- Relacije}

Relacije so definirane kot povezava med domeno (ali definicijskim območjem) in zalogo vrednosti. Poenostavljeno jih lahko poimenujemo povezave med »prvo entiteto« in »drugo entiteto«. Vse relacije so deklarirane v obeh smereh, in čeprav so deklarirane med entitetnimi tipi, dejansko obstajajo med konkretnimi primerki entitet (Žumer, 2017). Relacije predstavljajo bistven del modela, saj povezujejo primerke entitet in jih postavljajo v kontekst.

$\checkmark$ modelu LRM je 36 relacij, središče modela predstavljajo relacije med entitetami delo, izrazna oblika, pojavna oblika in enota (angl. work, expression, manifestation and item, WEMI) in so edini del, ki je $v$ bistvu obvezen. Relacije odgovornosti je zelo poenostavila uvedba splošne entitete agent, ki omogoča vzpostavljanje povezav med agenti in entitetami WEMI, kar je bilo pomembno tudi za našo implementacijo.

\section{- Agregati}

Kot odgovor na zaznane pomanjkljivosti pri modeliranju publikacij, ki vključujejo več izraznih oblik, je Delovna skupina za agregate pripravila dodatek, ki je bil v celoti vključen v LRM. Modeliranje agregatov kot pojavnih oblik z več neodvisnimi izraznimi oblikami je pregledno, saj so dela in pripadajoče izrazne oblike neodvisni od tega, kako so objavljeni. Izrazna oblika ostaja nespremenjena, če je objavljena samostojno ali skupaj z drugimi izraznimi oblikami (Žumer, 2017).

Ločimo naslednje tri tipe agregatov:

1) agregatne zbirke, ki predstavljajo pojavne oblike, v katerih so zbrane neodvisno ustvarjene izrazne oblike iste vrste ali žanra (npr. zbrana in izbrana dela, antologije, znanstveni časopisi, ki so agregati člankov, monografske publikacije z neodvisno ustvarjenimi poglavji, zvočni posnetki na CD-ju, več novel, objavljenih v eni knjigi, ipd.);

2) agregati $z$ dodatki, ki se od agregatnih zbirk razlikujejo po tem, da $v$ njih najdemo neodvisno samostojno delo, ki ga dopolnjujejo odvisna dela (npr. ilustracije, spremne besede, opombe ipd.), in

3) agregatne vzporednice, o katerih govorimo, kadar pojavna oblika vključuje dve ali več izraznih oblik istega dela (npr. priročniki ali uradne publikacije $v$ več jezikih, izvirnik skupaj $s$ prevodom, dvojezična poezija, spletne strani s prevodi v različne jezike ipd.) (Žumer, 2017).

\subsubsection{Funkcionalne zahteve}

Da bi dosegli glavne cilje konceptualne zasnove, mora prototipni sistem podpirati katalogizatorje pri naslednjih opravilih:

- kreiranje in dopolnjevanje ločenih zapisov za vsako posamezno entiteto;

- vzpostavitev normativne kontrole za dela in izrazne oblike;

- vzdrževanje normative za agente;

- vzpostavitev odnosov med različnimi entitetami;

- pregleden način vnosa za agregate (različne izrazne oblike del v isti pojavni obliki): 
- agregati z dodatki,

- agregatne zbirke,

- agregatne vzporednice;

- možnost izbire vrstnega reda vnosa podatkov, preskakovanja in pregleda nad vsemi entitetami;

- pregled zapisov v strukturi WEMI med katalogizacijo;

- ponovna uporaba vrednosti atributov;

- prevzemanje zapisov;

- preverjanje zapisov (manjkajočih in nepravilnih podatkov);

- preprečevanje napak ( $v$ vmesniku se prikažejo samo polja, ki se nanašajo na določeno entiteto, nato se podatki vpisujejo $v$ za to predvidena polja; sprotna pomoč pri vsakem polju).

\subsection{Zasnova prototipa}

Zasnova skladnega konceptualnega modela, osredotočenega na naloge, je temeljni in po navadi prvi korak v procesu zasnove vsakega sistema (Johnson in Henderson, 2011). Namen konceptualne zasnove je, da se koncepti in njihovi odnosi pravilno vzpostavijo in se s tem omogoči želen potek dela. Konceptualni model ima velik vpliv na to, kaj je mogoče opisati z metapodatki in kaj je mogoče $z$ njimi storiti. Na žalost je konceptualna zasnova $v$ razvoju programske opreme pogosto preskočena, kar se posledično kaže s preveč zapletenimi sistemi, ki uporabnikom izpostavljajo nepomembne koncepte (Johnson in Henderson, 2011).

V našem primeru konceptualni model LRM že obstaja, vendar je precej splošen in abstrakten, zato predstavlja le osnovo za načrtovanje bibliografskih informacijskih sistemov (Riva et al., 2017). Pri implementaciji smo upoštevali osnovne strukture entitet in odnosov med njimi, definirane atribute za posamezne entitete pa smo ustrezno dopolnili in nadgradili, tudi ob upoštevanju rezultatov raziskav s katalogizatorji.

LRM, kot rečeno, ne predpisuje vseh atributov in relacij za različne vrste publikacij, prav tako še ne obstajajo sprejeti standardizirani aplikacijski profili za različne vrste gradiva, zato smo se pri zasnovi oprli na katalogizacijska pravila RDA, ki so osnovana na LRM in na katera bomo $v$ prihodnosti prešli tudi v Sloveniji. Dodani so bili še nekateri dodatni atributi in relacije, ki v glavnem izhajajo iz trenutne katalogizacijske prakse in potreb končnih uporabnikov ter predlogov katalogizatorjev, ki smo jih pridobili z raziskavami, npr. velikost tiska, vzorčna stran, naslovnica, ohranjenost, vezava itd. (Pauman Budanović, 2019). Tabela 1 prikazuje atribute, vključene v podatkovni model prototipa. Treba je poudariti, da tudi ta nabor ni izčrpen, saj smo poskušali zagotoviti le najpomembnejše atribute, potrebne za uporabniška opravila, ki jih mora sistem omogočiti in podpirati, ter jih implementirali $v$ prototipni sistem. Dejanski aplikacijski profil bo treba prilagoditi katalogizacijskemu okolju, odgovorne institucije pa bodo določile, katere elemente mora vključevati. Pri konceptualni zasnovi se nismo ukvarjali s tem, kako vrednosti atributov izberemo in kakšna je njihova oblika. Ko bodo sprejeta katalogizacijska pravila (RDA), bodo določala izbiro, obliko in obveznost elementov. 
Tabela 1: Nabor atributov prototipnega sistema za katalogizacijo

\begin{tabular}{|c|c|c|c|}
\hline $\begin{array}{l}\text { AGENT } \\
\text { (oseba) }\end{array}$ & $\begin{array}{l}\text { Identifikator agenta } \\
\text { Normativna točka dostopa } \\
\text { Normativna oblika imena } \\
\text { Variantne oblike imena } \\
\text { Datum rojstva } \\
\text { Datum smrti } \\
\text { Spol } \\
\text { Kraj rojstva } \\
\text { Država, povezana z agentom } \\
\text { Kontaktni podatki } \\
\text { Jezik } \\
\text { Področje dejavnosti } \\
\text { Stroka/poklic } \\
\text { Identifikator dela } \\
\text { Naslov dela } \\
\text { Variantni naslov } \\
\text { Oblika dela } \\
\text { Ciljna skupina } \\
\text { Datum dela } \\
\text { Reprezentativna izrazna } \\
\text { oblika: } \\
\text { Izvirni jezik } \\
\text { Zvrst } \\
\text { Ciljna skupina } \\
\text { reprezentativne izrazne } \\
\text { oblike }\end{array}$ & POJAVNA OBLIKA & $\begin{array}{l}\text { Identifikator pojavne oblike } \\
\text { Naslov pojavne oblike } \\
\text { Ostali naslovi } \\
\text { Navedba pojavne oblike } \\
\text { Ciljna skupina } \\
\text { Oznaka izdaje } \\
\text { Država izida ali izdelave } \\
\text { Ime založnika/distributerja } \\
\text { Kraj izida/distribucije } \\
\text { Leto izida/distribucije } \\
\text { Izdelovalec } \\
\text { Kraj izdelave } \\
\text { Naslov zbirke } \\
\text { Vzporedni naslov zbirke } \\
\text { Številčenje v zbirki } \\
\text { Vrsta nosilca } \\
\text { Vrsta medija } \\
\text { Obseg nosilca } \\
\text { Mere nosilca } \\
\text { Pisava } \\
\text { Velikost tiska } \\
\text { Tipografija } \\
\text { Vzorčna stran } \\
\text { Naslovnica }\end{array}$ \\
\hline IZRAZNA OBLIKA & $\begin{array}{l}\text { Identifikator izrazne oblike } \\
\text { Naslov izrazne oblike } \\
\text { Ciljna skupina } \\
\text { Stopnja (pred)znanja } \\
\text { Kategorija/vrsta vsebine } \\
\text { Jezik izrazne oblike } \\
\text { Datum izrazne oblike } \\
\text { Obseg } \\
\text { Pravice uporabe }\end{array}$ & ENOTA & $\begin{array}{l}\text { Identifikator enote } \\
\text { Lokacija } \\
\text { Pravice uporabe } \\
\text { Ohranjenost } \\
\text { Vezava (trda, mehka, posebna) } \\
\text { Prevezava }\end{array}$ \\
\hline
\end{tabular}

\subsection{Razvoj prototipa na papirju}

Razvoja prototipnega sistema smo se lotili sistematično ob upoštevanju vseh podatkov in ugotovitev, pridobljenih s predhodnimi raziskavami, ki so služile kot osnova za načrtovanje prototipa na papirju. Upoštevali smo poročila, ki se nanašajo na LRM, in nekatere primere implementacij modela LRM v katalogizacijska orodja. Razvoj prototipa na papirju je potekal na osnovi različnih scenarijev katalogizacije monografskih publikacij (natančneje: opisne katalogizacije). Za načrtovanje interakcije med sistemom in uporabnikom (katalogizatorjem) smo uporabili naslednje scenarije, ki jih mora prototip podpirati: 
- kreiranje normativnega zapisa za delo, izrazno obliko in zapisa za pojavno obliko;

- kreiranje normativnega zapisa za agenta;

- prevzemanje normativnega zapisa za agenta;

- prevzemanje normativnega zapisa za delo, kreiranje normativnega zapisa za izrazno obliko in zapisa za pojavno obliko;

- prevzemanje normativnih zapisov za delo in izrazno obliko, kreiranje zapisa za pojavno obliko;

- prevzemanje normativnih zapisov za delo in izrazno obliko ter zapisa za pojavno obliko.

V Pauman Budanović (2019) je podrobneje opisan niz scenarijev, ki pokrivajo funkcionalnost našega prototipa za tipične situacije, s katerimi se srečujejo katalogizatorji. Za ilustracijo je $v$ tabeli 2 prikazan del postopka kreiranja normativnega zapisa za delo.

Tabela 2: Del postopka kreiranja normativnega zapisa za delo

\begin{tabular}{|c|c|c|}
\hline \multicolumn{3}{|l|}{ DELO 1} \\
\hline $\begin{array}{l}\text { Samodejni vnos pri kreiranju } \\
\text { novega dela }\end{array}$ & Identifikator dela & D1 \\
\hline Vnesite izvirni naslov & Naslov dela & Romeo and Juliet \\
\hline Vnesite variantni naslov & Variantni naslov & $\begin{array}{l}\text { The tragedy of Romeo and } \\
\text { Juliet }\end{array}$ \\
\hline Izberite s seznama & Oblika dela & drama \\
\hline Vnesite datum dela & Datum dela & 1593 \\
\hline Izberite s seznama & Ciljna skupina & odrasli (splošno) \\
\hline
\end{tabular}

Na osnovi analize zahtev in različnih scenarijev uporabe smo oblikovali zasnovo uporabniškega vmesnika za implementacijo predlaganega modela v prototipni sistem in pripravili zasnovo prototipa na papirju, kar je pogosta prva faza $v$ razvoju programske opreme. Proces prototipiranja smo začeli z izdelavo preprostih skic (angl. mockup) posameznih delov uporabniškega vmesnika, ki smo jih postopno razvijali in združevali, da bi prikazali del funkcionalnosti prototipa, ki se nanaša na vnos podatkov. Pri izdelavi prototipa uporabniškega vmesnika nam je bilo v pomoč orodje za izdelavo prototipov InVision. ${ }^{3}$

Glavni izziv pri zasnovi uporabniškega vmesnika je bil, kako predstaviti različne nivoje abstraktnosti ustvarjalnih del in kako pri tem najbolje podpreti miselni proces katalogizatorja. To smo poskušali doseči z urejevalnikom zapisov, ki je organiziran na osnovi zavihkov za dela, izrazne oblike, pojavne oblike, enote in agente, znotraj katerih so obrazci za vnos posameznih sklopov podatkov oziroma za vnos vrednosti atributov. Zavihki omogočajo kreiranje in urejanje ločenih zapisov za vsako posamezno entiteto ter vzpostavljanje odnosov med njimi, hkrati pa omogočajo združevanje potencialno velike količine podatkov (npr. v zapisu za pojavno obliko) $\checkmark$ posamezne sklope. Uporabniški vmesnik je predstavljen v naslednjem poglavju.

Treba je bilo določiti tudi način vnosa za podatke, pri čemer smo upoštevali rezultate opravljenih raziskav miselnih modelov katalogizatorjev, njihove predloge in trenutni način dela (vnos podatkov, spustni seznam, označevanje ipd.).

\footnotetext{
3 InVision. (n.d.). InVisionApp Inc., https://www.invisionapp.com/about/ .
} 
Z uporabo različnih tipičnih scenarijev katalogizacije in sprotnega testiranja smo postopoma izboljševali prototipe in odpravljali napake.

\subsection{Testiranje prototipa}

Testiranje prototipa je potekalo tako med razvojem kot tudi po njem. $V$ fazi vrednotenja začetnih zamisli (idejne zasnove in delovni prototipi) smo razmišljali predvsem o ciljih uporabe katalogizacijskega sistema, cilje uporabnikov (katalogizatorjev) smo usklajevali $\mathrm{s}$ konceptualnim modelom LRM, identificirali smo morebitne omejitve in vrednotili funkcionalnost (katere funkcije bomo uporabili). Ob sprotnem preverjanju med razvojem prototipnega sistema smo $\mathrm{v}$ zadnji fazi opravili testiranje prototipa na papirju $z$ uporabniško študijo, v kateri je sodelovalo sedem katalogizatorjev (Pauman Budanović in Žumer, 2021b). Preverjali smo tako vizualne vidike vmesnika kot njegovo funkcionalnost. $V$ ta namen smo uporabili kombinacijo fokusne skupine, ki je služila za pridobivanje splošnih mnenj o prototipu, in metodo čarovnik iz Oza, s katero smo preizkusili nekaj tipičnih scenarijev uporabe. Fokusna skupina omogoča hitro razumevanje dojemanja uporabnikov o določeni temi ali konceptu, njena prednost je tudi to, da skupinska dinamika pripelje do tem, na katere raziskovalec ni pomislil, ali do novih idej (Baxter et al., 2015). Metoda čarovnik iz Oza (angl. the wizard of Oz) pa je simulacijska tehnika, ki omogoča preverjanje interakcije uporabnikov s sistemom $v$ vseh fazah razvoja (Fraser et al., 2013). Prvi test s fokusno skupino daje zelo obetavne rezultate, saj kaže na ustreznost zasnove uporabniškega vmesnika. Čeprav so imeli katalogizatorji nekaj težav z razumevanjem modela LRM, je predlagani prototip olajšal njihovo razumevanje modela in je bil zato dobro ocenjen: zdel se jim je precej enostaven za uporabo, hiter za razumevanje in pregleden. Funkcionalnost predlaganega prototipa se je izkazala kot ustrezna, saj so udeleženci brez večjih težav in napak uspešno opravili vse naloge. Končno preverjanje prototipa s katalogizatorji je hkrati služilo za pridobivanje novih zahtev za izboljšavo prototipa, kar predstavlja izhodišče za nove iteracije, ki se praviloma nadaljujejo, dokler niso izpolnjene vse uporabniške zahteve.

\section{Opis uporabniškega vmesnika za katalogizacijo}

Pri načrtovanju uporabniškega vmesnika za katalogizacijo smo poskušali čim bolj upoštevati ugotovitve raziskav, $v$ katerih se je izkazalo, da se zdi mnogim katalogizatorjem vmesnik za katalogizacijo COBISS3/Katalogizacija pregleden in da je okolje Windows precej intuitivno (Pauman Budanović, 2019). Te ugotovitve smo poskušali upoštevati z razdelitvijo vmesnika na dva dela, tako kot je razdeljena COBISS3/Katalogizacija, in z ohranitvijo okolja Windows, ki so ga katalogizatorji vajeni.

Levi del uporabniškega vmesnika je namenjen iskanju in brskanju ter pregledu zapisov in strukture WEMI, desni (urejevalnik zapisa) pa vnosu in urejanju podatkov.

Glavni elementi vmesnika za katalogizacijo so (slika 2):

- naslovna vrstica z imenom entitete, ki je predmet katalogizacije;

- menijska vrstica, ki vsebuje več metod (iskanje, zapis, urejanje itd.), s katerimi izvajamo določene katalogizacijske postopke;

- orodna vrstica z nizom oken in ikon, ki omogočajo hiter dostop do pogosto uporabljenih metod (iskanje, zapis za entiteto, prikaz strukture WEMI, shrani, izbriši, kreiraj nov zapis, osveži); 
- vrstica z zavihki, ki omogoča izbor zapisa za entiteto, ki se kreira ali ureja (desna stran vmesnika);

- podokna z obrazci, ki vsebujejo seznam atributov za posamezne entitete, kamor vnašamo vrednosti atributov.

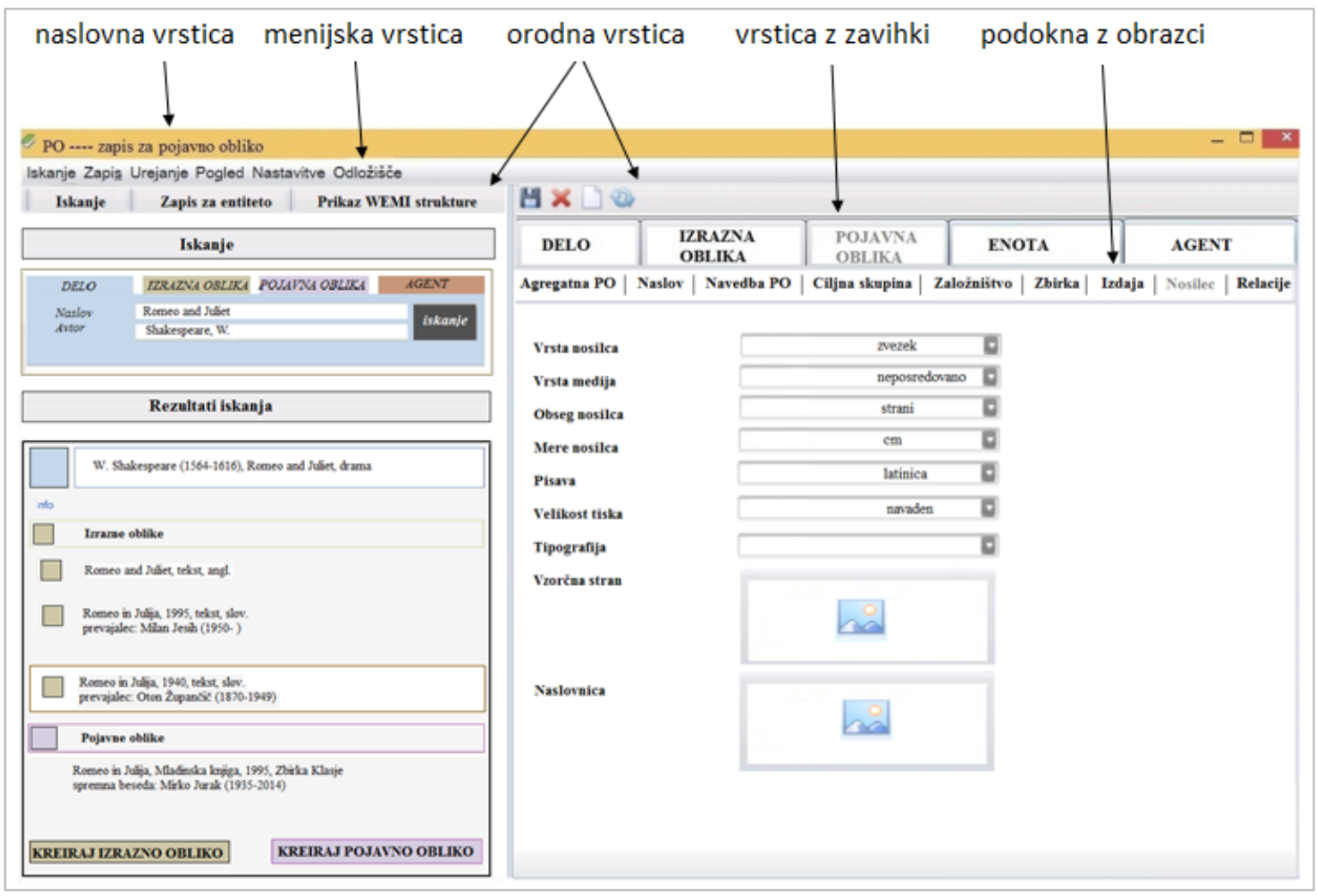

Slika 2: Uporabniški vmesnik sistema za katalogizacijo

Na levi strani uporabniškega vmesnika je iskalnik (slika 3), ki na osnovi zavihkov omogoča iskanje po različnih entitetah (WEMI in agent). Pod njim so prikazani rezultati iskanja. Posamezne rezultate iskanja je možno razširiti s klikom na izbrani zapis, kar omogoča prikaz podrobnejših podatkov za posamezne entitete in raziskovanje odnosov med njimi. Pri rezultatih iskanja je omogočena tudi izbira posamezne entitete (ali več entitet), ki jo/jih bomo prevzeli, povezali ali uredili, potem ko jo/jih najprej prenesemo (na desno stran). Če bi bil prototip funkcionalen, bi se entitete $v$ urejevalnik prenašale na več načinov (npr. $z$ desnim klikom na miški, bližnjico na tipkovnici ipd.) Za boljšo preglednost in navigacijo so entitetam dodane barve. 


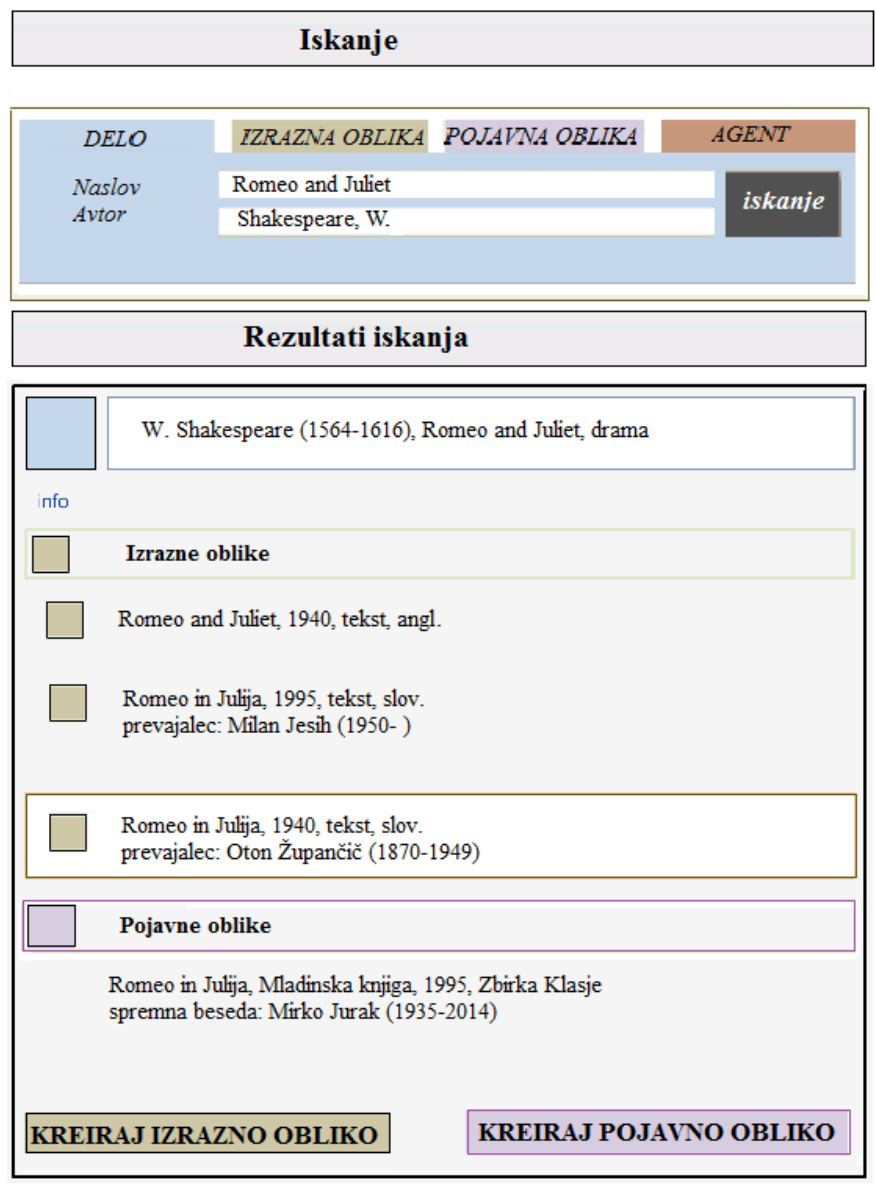

Slika 2: Iskalnik

Med kreiranjem zapisov lahko na levi strani pregledujemo zapise $v$ strnjeni in razširjeni obliki (slika 4) ter relacije med entitetami, kar omogoča prikaz strukture WEMI (slika 5).

\begin{tabular}{|l|l|}
\hline \multicolumn{2}{|c|}{ Zapis za entiteto pojavna oblika } \\
\hline Ime atributa & \multicolumn{1}{|c|}{ Vrednost } \\
\hline Naslov & \\
Dodatek k naslovu & \\
Vzporedni naslov & \\
Variantni naslov & \\
Skrajšani naslov & \\
Ciljna skupina & \\
Navedba založništva & \\
\hline Država izida ali izdelave & \\
Ime založnika/distributerja & \\
\hline Kraj izida/distribucije \\
Leto izida/distribucije
\end{tabular}

Slika 3: Prikaz zapisa za entiteto pojavna oblika v razširjeni obliki 


\section{DELA}

(kreiraj/poveži)

\begin{tabular}{|c|}
\hline DELO 1 \\
\hline DELO 2 \\
\hline DELO $\mathrm{n}$ \\
\hline
\end{tabular}

se izrazi(jo) $v$

VKLJUČENE IZRAZNE OBLIKE

(kreiraj/poveži)

\begin{tabular}{|c|}
\hline IO 1 \\
\hline IO 2 \\
\hline IO $\mathrm{n}$ \\
\hline
\end{tabular}

utelešene $v$

$$
\text { AGREGATNA POJAVNA OBLIKA }
$$

Slika 4: Prikaz strukture WEMI

$\mathrm{Na}$ desni strani uporabniškega vmesnika je urejevalnik zapisa, ki je strukturiran na osnovi zavihkov (slika 6). Osrednji del predstavlja vrstica z zavihki za entitete delo, izrazna oblika, pojavna oblika, enota in agent, znotraj katerih so obrazci za vnos posameznih sklopov podatkov oziroma za vnos vrednosti atributov. Obrazec za vnos podatkov za pojavno obliko na primer vključuje devet zavihkov. $V$ obrazcu za nosilec so vključeni naslednji atributi: vrsta nosilca, vrsta medija, obseg nosilca, mere nosilca, pisava itd. Katalogizator se med zavihki premika tako, da klikne na določen zavihek, nakar se mu odpre obrazec za vnos podatkov. Predvidene so tudi bližnjice na tipkovnici (TAB). Pri poljih, v katerih je predvidenih več vrednosti podatkov, se na desni strani prikaže simbol + in s klikom nanj se doda novo polje. 


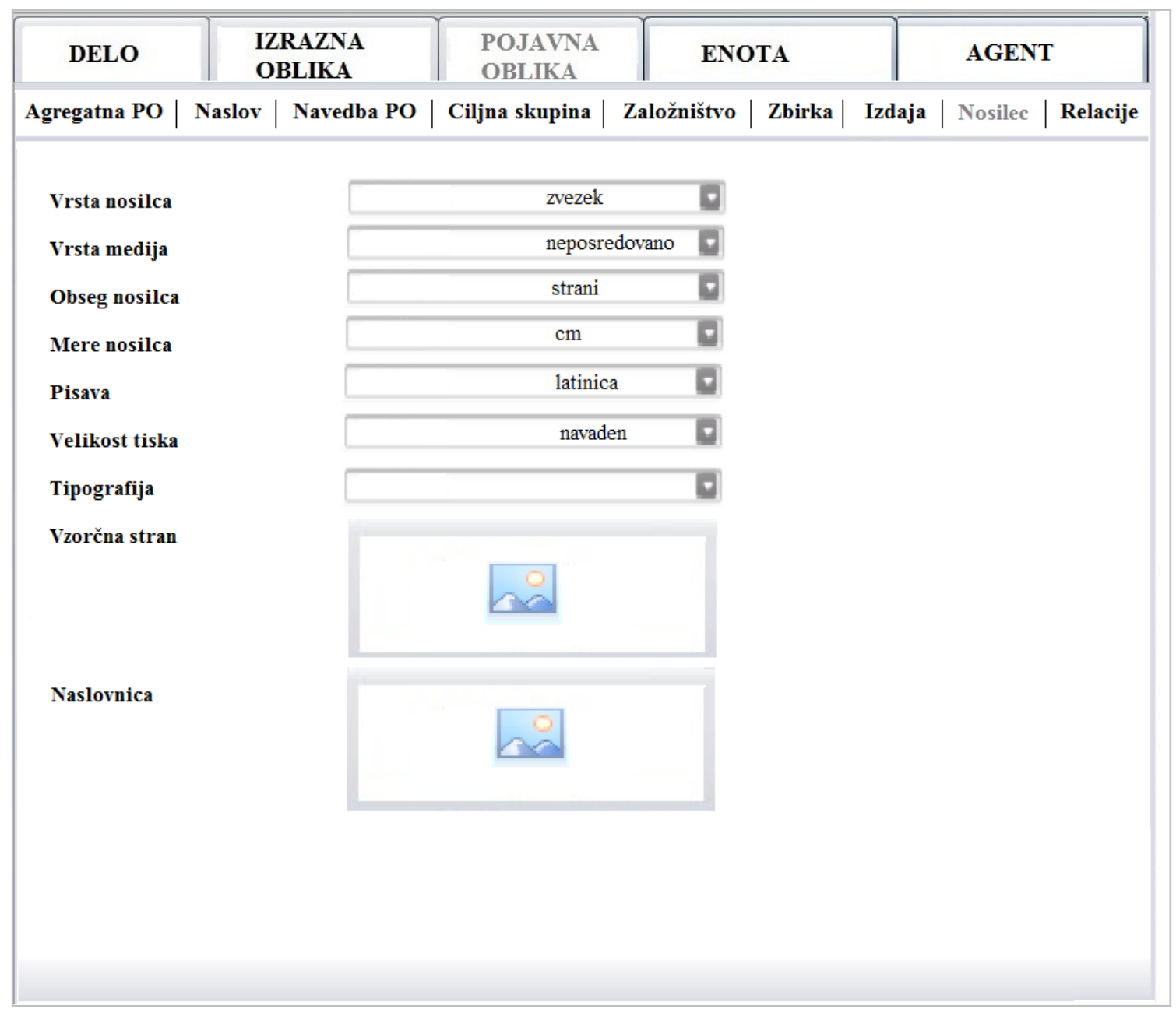

Slika 5: Urejevalnik zapisa za pojavno obliko

Slika 7 prikazuje obrazec za vnos relacij. Primarni odnosi med entitetami WEMI se ustvarijo samodejno. Povezave za vse druge odnose se kreirajo z uporabo spustnega seznama in so omogočene v obe smeri, npr. ima prevod/je prevod. 


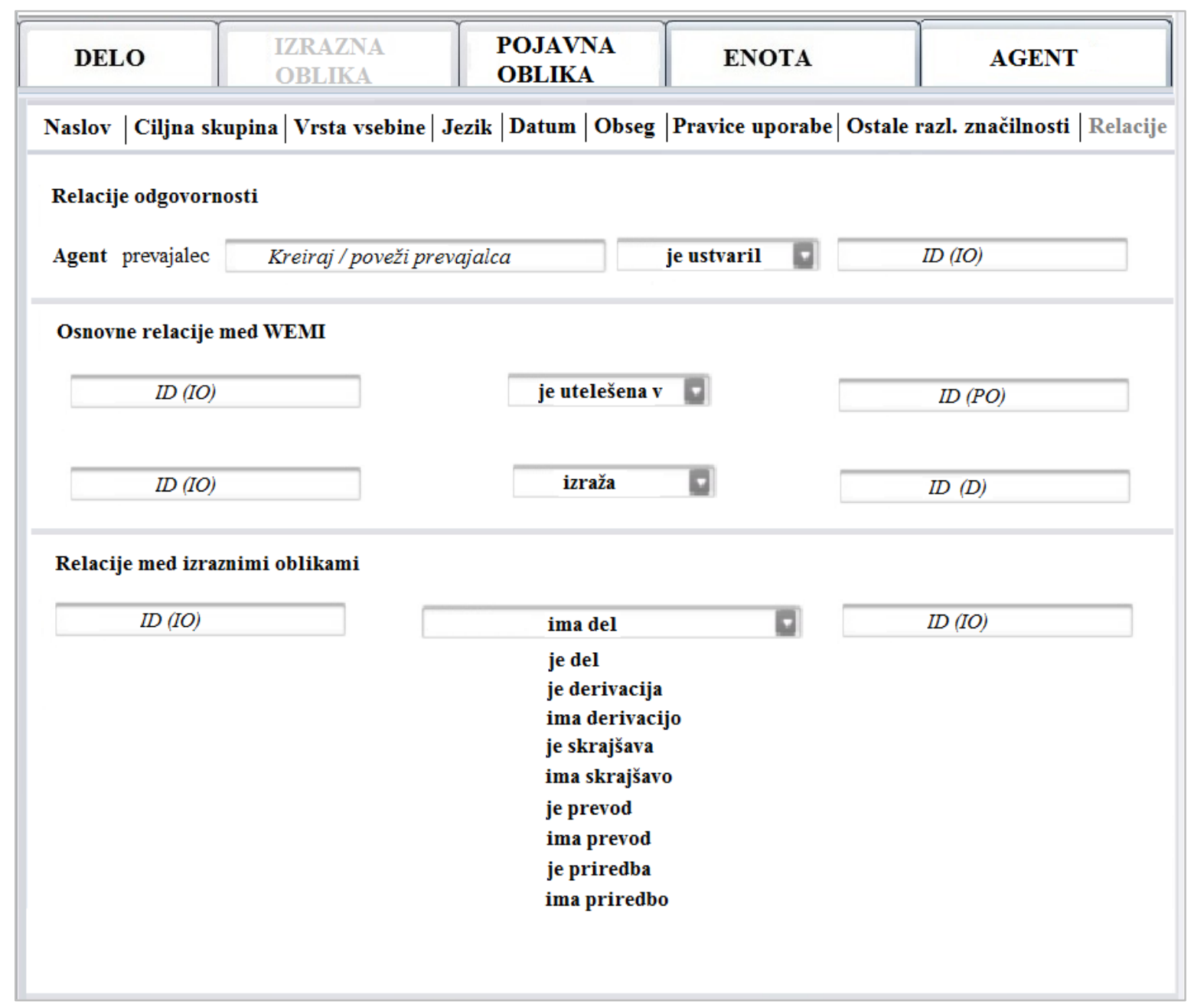

Slika 6: Prikaz vnosa relacij (primer izrazne oblike)

Pri zasnovi smo posebno pozornost namenili agregatom. $V$ vmesniku je poseben zavihek za vnos podatkov za agregatne pojavne oblike. Za vsak tip agregatov (za agregatne zbirke, agregate $z$ dodatki in agregatne vzporednice) obstaja obrazec za vnos podatkov, ki je prilagojen naravi takih publikacij (slike 8-10).

Eden od najpogostejših scenarijev katalogizacije so publikacije z dodatki, kot so spremne besede in ilustracije. Da bi čim bolj poenostavili postopek katalogizacije, je pri kreiranju osnovnih del, kot so npr. spremne besede, obvezen le vnos avtorja (če je znan), naslova, ciljne skupine in oblike dela. Pri spremni besedi smo dodali še lokacijo (kje v pojavni obliki je) in obseg ter primernost za domače branje. $\mathrm{S}$ tem želimo končnim uporabnikom olajšati identifikacijo in izbiro, saj se je $v$ naših raziskavah izkazalo, da po izkušnjah katalogizatorjev predvsem šolajoče se uporabnike pogosto zanima, kako obsežna je spremna beseda in ali je primerna za domače branje ali ne (slika 8). 


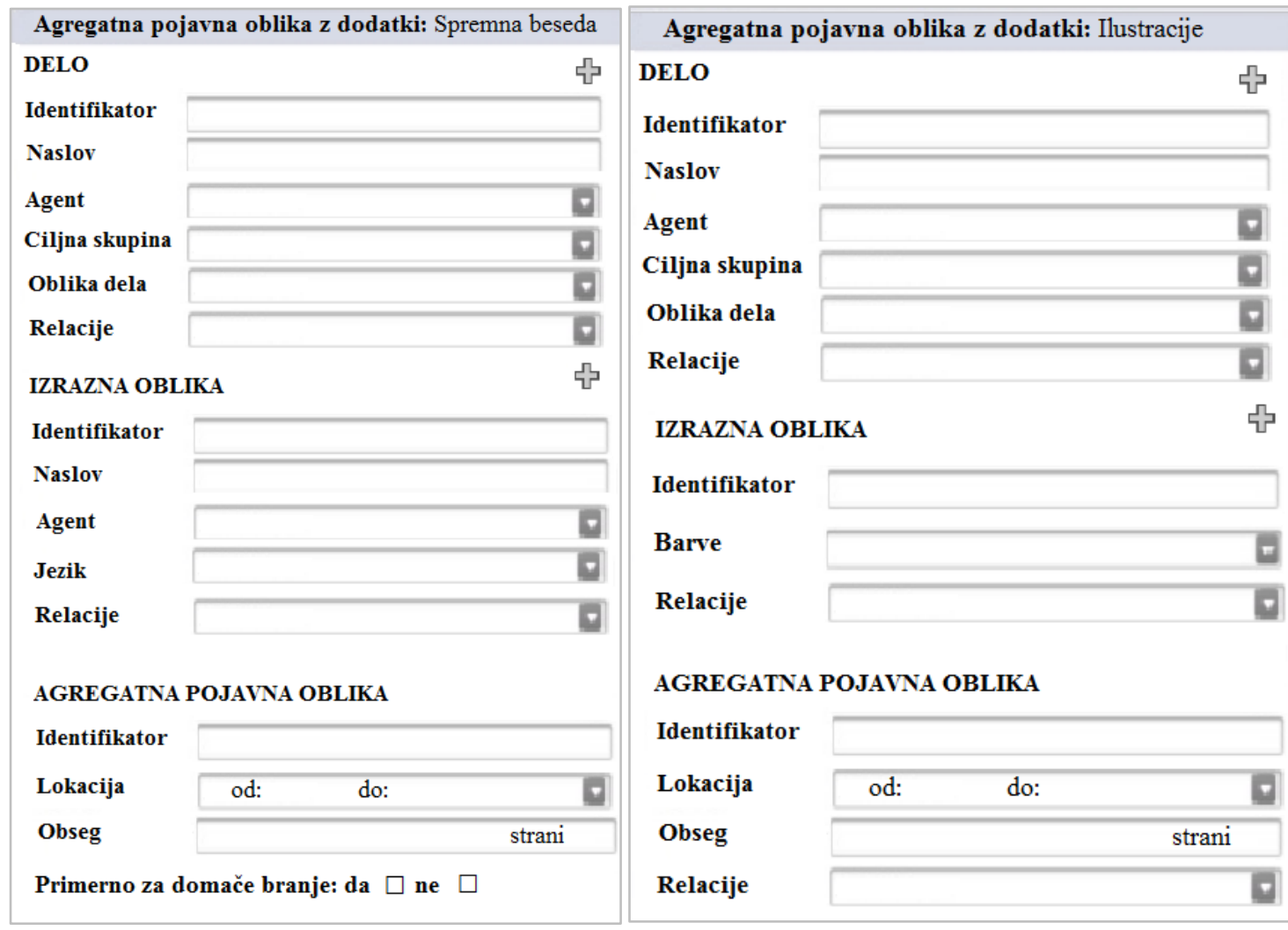

Slika 7 (levo): Obrazec za vnos podatkov za spremno besedo Slika 8 (desno): Obrazec za vnos podatkov o ilustracijah

\begin{tabular}{|c|c|c|c|c|c|c|c|c|}
\hline DELO & & $\begin{array}{l}\text { RAZNA } \\
\text { BLIKA }\end{array}$ & $\begin{array}{l}\text { POJAVNA } \\
\text { OBLIKA }\end{array}$ & \multicolumn{2}{|c|}{ ENOTA } & \multicolumn{3}{|c|}{ AGENT } \\
\hline Agregatna $\mathrm{PO}$ & Naslov & Navedba PO & Ciljna skupina & Založništvo & Zbirka & Izdaja & Nosilec & Relacije \\
\hline \multicolumn{3}{|c|}{ Agregatna zbirka: več dram } & \multicolumn{6}{|c|}{ Agregatne vzporednice: izvirnik + prevod } \\
\hline DELO & & & 乡 & \multirow{3}{*}{$\begin{array}{l}\text { DELO } \\
\text { Identifikator } \\
\text { Naslov }\end{array}$} & & & & 引 \\
\hline Identifikator & & & & & & & & \\
\hline Naslov & & & & & & & & \\
\hline Agent & & & - & \multirow{2}{*}{$\begin{array}{l}\text { Agent } \\
\text { Ciljna skupina }\end{array}$} & & & & - \\
\hline Ciljna skupina & & & D & & & & & 7 \\
\hline Oblika dela & & & 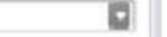 & \multirow{2}{*}{$\begin{array}{l}\text { Oblika dela } \\
\text { Relacije }\end{array}$} & & & & 7 \\
\hline Relacije & & & I. & & & & & (1) \\
\hline \multicolumn{3}{|c|}{ IZRAZNA OBLIKA } & Љ & \multicolumn{2}{|c|}{ IZRAZNA OBLIKA } & & & ફ \\
\hline Identifikator & & & & Identifikator & & & & \\
\hline Naslov & & & & Naslov & & & & \\
\hline Agent & & & 7 & Agent & & & & - \\
\hline Jezik & & & (1) & Jezik & & & & - \\
\hline Relacije & & & - & Relacije & & & & - \\
\hline
\end{tabular}

Slika 9: Obrazec za vnos agregatne zbirke in agregatne vzporednice 


\section{Diskusija}

Ob kompleksnosti sprememb, ki jih $v$ katalogizacijsko teorijo in prakso prinaša uvajanje konceptov entitetno-relacijskega modela LRM, in raznolikosti miselnih procesov katalogizatorjev je bilo treba zasnovati vmesnik za katalogizacijo tako, da kar najbolje ustreza katalogizatorjevemu miselnemu procesu, hkrati pa smiselno izkorišča prednosti modela LRM.

Glavni namen zasnove uporabniškega vmesnika je bil prikazati, kako bi bil lahko videti katalogizacijski vmesnik, zasnovan na osnovi modela LRM, in kako bi tak vmesnik izboljšal obstoječi proces katalogizacije. Predstavili smo možen pristop za učinkovitejši vnos bibliografskih podatkov oziroma proces katalogizacije, ki prinaša manj podvojenega dela, nepotrebnega ponavljanja in boljšo izkoriščenost katalogizacije, kar smo poskušali uresničiti z implementacijo modela LRM, njegovih entitet, atributov in relacij. Osnova sistema je normativna kontrola del in izraznih oblik (poleg agentov, ki jih vključujejo že sedanji sistemi). Čeprav bi bilo na začetku za vzpostavitev čim natančnejše normativne kontrole za dela in izrazne oblike potrebno nekaj več dela, bi bilo le-to bolj intelektualno hvaležno, dolgoročno pa bi tak potek katalogizacijskega procesa katalogizatorjem prihranil veliko časa, ker jim ne bi bilo treba navajati istih podatkov za vsako pojavno obliko, povezano z določenim delom oziroma izrazno obliko. Končnim uporabnikom pa bi olajšal iskanje, brskanje in raziskovanje, saj prednosti normativnih zapisov za dela in izrazne oblike omogočajo več neposrednih povezav tako med deli in izraznimi oblikami kot tudi med njihovimi avtorji, prevajalci ipd.

Pri konceptualni zasnovi uporabniškega vmesnika za katalogizacijo smo želeli doseči tudi čim boljše skladanje miselnih modelov katalogizatorjev z novim sistemom, zato je bil razvojni proces $v$ vseh fazah usmerjen $v$ katalogizatorje, saj smo jim poskušali omogočiti kvalitetno delo na način, ki bi sledil njihovemu naravnemu toku aktivnosti. Rezultati predhodnih raziskav miselnih procesov so nas vodili v razmišljanje, kako zasnovati prototip, ki bo hkrati upošteval konceptualni model LRM in miselne procese katalogizatorjev. Iz rezultatov raziskav prostega opisa publikacij (Pauman Budanović in Žumer, 2018) izhaja, da so miselni procesi katalogizatorjev zelo različni in se obravnave posamezne publikacije lotevajo na različnih ravneh abstrakcije. Zato mora biti uporabniški vmesnik fleksibilen in omogočati ločen vnos posameznih entitetnih tipov. Med drugim se je pri prostem opisu publikacij izkazalo, da katalogizatorji podatek največkrat omenijo, ko ga opazijo, zato jim je treba omogočiti, da ga na tak način tudi enostavno vnesejo.

Podporo miselnemu procesu katalogizatorjev smo poskušali doseči z uporabo zavihkov, ki omogočajo kreiranje in urejanje ločenih zapisov za vsako posamezno entiteto ter vzpostavljanje odnosov med njimi. Organizacija uporabniškega vmesnika na osnovi zavihkov omogoča tudi boljši pregled nad entitetami in enostaven dostop do obrazcev za vnos podatkov med celotnim katalogizacijskim procesom. Katalogizatorji lahko vsak podatek hitro in enostavno vnesejo, ko ga opazijo, enostavno prehajajo med zavihki in jih po potrebi preskakujejo, saj vmesnik ne sili v sledenje vnaprej določenemu vrstnemu redu polj. Sistem seveda še vedno omogoča, da katalogizatorji sledijo določenemu vrstnemu redu polj ali pa si po želji prilagodijo zavihke in s tem uvedejo lasten pristop h kreiranju zapisov. Razen podpore miselnemu procesu zavihki omogočajo tudi združevanje potencialno velike količine podatkov (npr. v zapisu za pojavno obliko) v posamezne sklope. Stalen pregled nad že vnesenimi podatki in povezavami med entitetami omogoča funkcija pregled zapisov $v$ strukturi WEMI. Za prikaz 
strukture WEMI bi bilo smiselno uporabiti vizualizacijske tehnike, ki jih predlaga Merčun (2012), saj bi njihova uporaba funkcionalnost sistema zagotovo izboljšala.

Sistem omogoča tudi pregleden način vnosa za agregate (različne izrazne oblike del $v$ isti pojavni obliki). Ločen vnos agregatov po eni strani katalogizatorjem omogoča enostavnejšo katalogizacijo le-teh, končnim uporabnikom pa bi tako olajšali oziroma omogočili njihovo najdenje, ki je $v$ trenutnih sistemih prav zaradi lokacije podatkov o agregatih (najpogosteje so ti podatki v opombah) oteženo ali celo onemogočeno. Tako bi tudi uporabniki kataloga hitro in enostavno prišli do strukturiranih informacij o ilustracijah, spremni besedi in drugih dodatkih.

Naše vodilo je bilo, da ustvarjamo za katalogizatorje, upoštevajoč tudi končne uporabnike. Katalog v skladu z LRM prikazuje odnose med entitetami, kar olajša navigacijo in uporabniku omogoča odkrivanje povezav med sorodnimi zadetki v katalogu. Omogoča namreč smiselno grupiranje zadetkov (npr. vseh prevodov/verzij istega dela; vseh izdaj, ki vsebujejo točno določeno besedilo in določene dodatke, kot so ilustracije in spremne besede); raziskovanje in sledenje relacijam (npr. sorodnim delom, kot sta knjiga in film; povezavam na nadaljevanje, povezavam na predelana dela ipd.).

Kar se tiče omejitev prototipa, je treba poudariti, da smo se pri zasnovi omejili le na leposlovje in opisni del katalogizacije. Prav tako je bil v predlaganem prototipu implementiran le osnovni nabor entitet LRM, vendar je njegova modularna zasnova zelo prilagodljiva za integracijo drugih entitet, kar bi bil lahko naš naslednji korak. Osredotočili smo se predvsem na funkcionalnost pri vnosu podatkov, za iskanje in prikaz podatkov pa smo prikazali le osnovne funkcije. Zavedamo se, da bi moral prototip za optimalno delovanje podpirati vse funkcije ter da bi delujoč prototip katalogizatorjem omogočal še boljši vpogled v novo katalogizacijsko paradigmo in bi lahko služil tudi kot ilustrativno orodje za usposabljanje in seznanjanje katalogizatorjev z modelom LRM, po vzgledu primerov iz tujine, npr. RIMMF (Dunsire et al., 2020). Potrebno bi bilo še veliko dopolnjevanja in testiranja prototipa, že zdaj pa je vidno, da je možno ustvariti katalogizacijski sistem, ki je primeren za nov katalogizacijski ustroj in je hkrati prilagojen razmišljanju katalogizatorjev.

\section{Zaključek}

Prihajajoče obdobje bo za katalogizacijsko skupnost polno izzivov in sprememb, ki so zelo zapletene in hkrati tesno povezane. Pred celovito implementacijo modela LRM bo namreč treba izpolniti vrsto zahtevnih pogojev na praktični ravni: treba se bo spopasti z novimi katalogizacijskimi pravili, morebitnimi novimi metapodatkovnimi formati, z uvedbo ali razvojem novih sistemov ter ustreznim usposabljanjem katalogizatorjev. Ponovna preučitev katalogizacijske prakse je nedvomno ključnega pomena, njen cilj pa bi moral biti tudi razvoj fleksibilnejših katalogizacijskih orodij, na osnovi katerih bi končnim uporabnikom zagotovili lažji dostop do informacij, katalogizatorjem pa učinkovitejši katalogizacijski proces.

Predlagani prototip uporabniškega vmesnika za katalogizacijo sicer ni rešitev, ki bi jo lahko hitro in enostavno prenesli $v$ katalogizacijsko prakso, a vendar s predstavitvijo konkretnih možnosti implementacije modela LRM $v$ katalogizacijski vmesnik in njegove uporabe prispeva $\mathrm{k}$ načrtovanju in razvoju na LRM osnovanih katalogizacijskih sistemov $v$ skladu $z$ razvojem $v$ svetu. Pri tem je treba upoštevati, da je bila celotna zasnova vezana na novo paradigmo bibliografskega univerzuma, ki se nenehno dopolnjuje, sprememb pa vedno ni možno povsem 
natančno predvideti. Zavedamo se, da je treba vse odločitve o zasnovi katalogizacijskega vmesnika uskladiti s pravili in drugimi predpisi, ki tvorijo strokovno osnovo vzajemnega kataloga ter knjižnično politiko, kljub temu pa verjamemo, da bi bile predlagane konkretne rešitve lahko uporabne pri razvoju novih katalogizacijskih sistemov oziroma njihovih verzij.

\section{Zahvala}

Za pomoč pri izvedbi raziskav se zahvaljujemo direktorjem knjižnic in vodjem oddelkov za katalogizacijo, vsem sodelujočim katalogizatorjem pa za ogromen prispevek k nastanku prototipa.

\section{Reference}

Baxter, K., Courage, C. in Caine, K., 2015. Understanding your users: a practical guide to user research methods. Amsterdam: Elsevier.

Behrens, R., 2020. EURIG annual meeting 2020: community reports. (Virtual Annual EURIG Meeting, 2020). Dostopno na: http://www.rdarsc.org/sites/all/files/RDA\%20in\%20Europe\%20May\%202020 0.pdf [5. 10. 2021].

Bibliographic Framework Initiative, 2021. Dostopno na: https://www.loc.gov/bibframe/ [11. 10. 2021].

Cronin, C., 2011. From testing to implementation: managing full-scale RDA adoption at the University of Chicago. Cataloging \& Classification Quarterly, 49(7-8), 626-646.

Dunsire, G., Fritz, D. in Fritz, R., 2020. Instructions, interfaces, and interoperable data: the RIMMF experience with RDA. Cataloging \& Classification Quarterly, 58(1), 44-58.

Fraser, N., Gilbert, N., McGlashan, S. in Wooffitt, R., 2013. Inspiration, observation and the wizard of $\mathrm{Oz}$. V: Humans, computers and wizards: human (simulated) computer interaction. London; New York: Routledge. Str. 36-50.

Funkcionalne zahteve za bibliografske zapise: končno poročilo, 2000. Ljubljana: Filozofska fakulteta.

Guerrini, M. in Possemato, T., 2016. From record management to data management: RDA and new application models BIBFRAME, RIMMF, and OliSuite/WeCat. Cataloging \& Classification Quarterly, 54(3), 197-199.

Hall-Ellis, S., 2015. The current state of bibliographic description. V: Weber, M. B. ur. Rethinking library technical services: redefining our profession for the future. Lanham, Maryland: Rowman and Littlefield. Str. 29-55.

Izjava o mednarodnih katalogizacijskih načelih, 2009. Haag: IFLA. Dostopno na: https://www.ifla.org/files/assets/cataloguing/icp/icp 2009-sl.pdf [11. 9. 2021].

Johnson, J. in Henderson, A., 2011. Conceptual models: core to good design. San Rafael: Morgan and Claypool.

KAM: Pravilnik za opis i pristup građi u knjižnicama, arhivima i muzejima, 2021. Dostopno na: https://pravilnik.kam.hr/ [15. 10. 2021]. 
Kavčič, I. in Šulek, S., 2017a. Identifikacija entitet in odnosov med entitetama delo in izrazna oblika v bibliografskih zapisih v podatkovni zbirki COBIB. Knjižnica, 61(1-2), 49-86.

Kavčič, I. in Šulek, S., 2017b. Revidirana Izjava o mednarodnih katalogizacijskih načelih (ICP), izdaja 2016 z manjšimi popravki, 2017. Knjižnica, 61(1-2), 251-260.

Kim, M., Chen, M. in Montgomery, D., 2021. Moving toward BIBFRAME and a linked data environment. V: Hines, S. S. ur. Technical services in the 21st century: advances in library administration and organization. Bingley: Emerald Publishing Limited. Str. 131-154.

Massey, V. in Satao, K. J., 2012. Evolving a new software development life cycle model (SDLC) incorporated with release management. International Journal of Engineering and Advanced Technology, 1(4), 25-31.

Merčun, T., 2012. Visualization of results and navigation support in user interfaces of bibliographic information systems. Disertacija. Ljubljana: Univerza v Ljubljani, Filozofska fakulteta.

Miksa, S., D., 2008. A survey of the extent and utilization of cataloging tools and resources within technical services in the North Texas public libraries. Journal of Education for Library and Information Science, 49(2), 128-146.

Park, J. R. in Tosaka, Y., 2015. RDA implementation and training issues across United States academic libraries: an in-depth e-mail interview study. Journal of Education for Library and Information Science, 56(3), 252-266.

Pauman Budanović, M., 2019. Konceptualna zasnova sistema za katalogizacijo na osnovi nove paradigme bibliografskega univerzuma. Disertacija. Ljubljana: Univerza v Ljubljani, Filozofska fakulteta.

Pauman Budanović, M. in Žumer, M., 2018. The catalogers' thought process: a comparison of formal and informal context. Cataloging \& Classification Quarterly, 56(5-6), 507-529.

Pauman Budanović, M. in Žumer, M., 2021a. Prototype cataloging interface based on the IFLA library reference model (LRM). Part 1: conceptual design. Cataloging \& Classification Quarterly, 59(7), 619-643. Dostopno na: https://doi.org/10.1080/01639374.2021.1974633 [27. 9. 2021].

Pauman Budanović, M. in Žumer, M., 2021b. Prototype cataloging interface based on the IFLA library reference model (LRM). Part 2: usability evaluation. Cataloging \& Classification Quarterly, 59(7), 644-668. Dostopno na: https://doi.org/10.1080/01639374.2021.197518 [27. 9. 2021].

Regole Italiane di catalogazione: REICAT, 2009. Roma: Istituto centrale per il catalogo unico delle biblioteche italiane e per le informazioni bibliografiche. Dostopno na:

https://www.iccu.sbn.it/export/sites/iccu/documenti/2015/REICAT-giugno2009.pdf [15. 10. 2021].

RDA toolkit: resource description and access, 2021. Chicago: ALA; Toronto: Canadian Federation of Library Associations; London: CILIP. Dostopno na: https://www.rdatoolkit.org/ [7. 10. 2021]. 
RDA: resource description and access, 2010. Chicago: American Library Association.

Riley, J., 2010. Enhancing interoperability of FRBR-based metadata. V: Hillmann, D. I. in Lauruhn, M. ur. Proceedings of the International Conference on Dublin Core and Metadata Applications. Pittsburgh: Dublin. Str. 31-43.

Riva, P., Le Boeuf, P. in Žumer, M., 2017. IFLA library reference model: a conceptual model for bibliographic information. Haag: IFLA.

Sandberg, J., 2015. Bibframe Editor. Technical Services Quarterly, 32(2), 220-221.

Sturman, R., 2005. Implementing the FRBR conceptual approach in the ISIS software environment: IFPA (ISIS FRBR prototype application). Cataloging \& Classification Quarterly, 39(3-4), 253-270.

Wacker, M. in Han, M. J., 2013. RDA planning, implementation and use: a comparison of two academic libraries. Alexandria, 24(2), 27-48.

Wright, J., 2018. How does true RDA cataloguing change how we catalogue? Dostopno na: http://library.ifla.org/2198/1/141-wright-en.pdf [7. 10. 2021].

Žumer, M., 2017. IFLA library reference model (IFLA LRM), pomemben korak k sodobnim bibliografskim informacijskim sistemom. Knjižnica, 61(1-2), 9-22. 